\title{
FNAC OF HIV LYMPHADENOPATHY IN A TERTIARY CARE HOSPITAL: A TWO YEAR STUDY
}

\author{
Sanjay Gajanan Surase1, Aradhana Bhubaneswar Deka², Vaishali Narayanrao Solanke3, Banasri Abinash Devi ${ }^{4}$ \\ ${ }^{1}$ Assistant Professor, Department of Pathology, Grant Government Medical College, J. J. Hospital, Byculla, Mumbai. \\ ${ }^{2} 3^{\text {rd }}$ Year Post Graduate Resident, Department of Pathology, Grant Government Medical College, J. J. Hospital, Byculla, Mumbai. \\ ${ }^{3}$ Assistant Professor, Department of Microbiology, Seth GSMC and KEMH, Parel, Mumbai. \\ ${ }^{4} 2^{\text {nd }}$ Year Post Graduate Resident, Department of Pathology, Grant Government Medical College, J. J. Hospital, Byculla, Mumbai.
}

\section{ABSTRACT}

The incidence of Human Immunodeficiency Virus (HIV) infection is seen to be increasing in Asia, particularly in the Indian subcontinent. Immune system and the central nervous system are the two major targets of this infection. HIV infection is often associated with a number of opportunistic infections and malignancies, presenting with lymphadenopathy which is one of the earliest manifestations of HIV infection. Hence, this study was done to evaluate the diagnostic utility of Fine Needle Aspiration Cytology (FNAC) for HIV positive lymphadenopathy patients and to analyse the different cytological diagnostic patterns of lymph node lesions in HIV/AIDS patients.

\section{MATERIALS AND METHODS}

A total of 70 cases were studied in this prospective study. Fine needle aspiration was done. Both alcohol fixed and air dried smears were prepared. Lymph node aspirates were stained with Haematoxylin and Eosin (H\&E), Papanicolaou's stain (PAP), Giemsa and Ziehl and Neelsen (ZN) stain. All these stains were done in all the cases irrespective of the cytological findings.

\section{RESULTS AND DISCUSSION}

In the present study, out of 70 HIV positive patients, 40 (57.14\%) were males and 30 (42.86\%) were females with a male-tofemale ratio of 1.3:1. Maximum affected patients were seen in the age group of 31-40 years. The most common site of HIV lymphadenopathy is the cervical lymph nodes 47 (67.14\%), followed by axillary 08 (11.44\%), inguinal, submandibular and supraclavicular $04(5.71 \%)$ cases each. The most common presentation was tuberculous lymphadenitis constituted about 42 $(60 \%)$ cases.

\section{CONCLUSION}

FNAC is reliable and inexpensive technique for evaluation and identification of opportunistic infections, neoplastic lesions and non-neoplastic lesions. In HIV patients, it helps in segregating cases which requires further evaluation. This is a quick and repeatable procedure which spare patients from lymph node excision and enable immediate treatment of specific infection.

\section{KEYWORDS}

Fine Needle Aspiration Cytology, Human Immunodeficiency Virus, Tuberculosis.

HOW TO CITE THIS ARTICLE: Surase SG, Deka AB, Solanke VN, et al. FNAC of HIV lymphadenopathy in a tertiary care hospital: a two year study. J. Evolution Med. Dent. Sci. 2016;5(59):4081-4085, DOI: 10.14260/jemds/2016/934

\section{INTRODUCTION}

Globally, about 34.0 million (31.4 million-35.9 million) people were living with HIV at the end of year 2011.[1] Although the epidemic burden of the disease considerably varies from countries and regions,[2] the incidence of human immunodeficiency virus (HIV) infection is seen to be increasing in Asia particularly in the Indian subcontinent.[3] Irrespective of the portal of entry of HIV; lymphoid tissues are the major anatomic sites for establishment and propagation of the infection with HIV.[4] India is found to have the third highest number of estimated people living with HIV/AIDS, after South Africa and Nigeria. As per the reports of HIV estimations 2012, India was estimated to have 20.89 lakh people living with HIV/AIDS with the adult

Financial or Other, Competing Interest: None.

Submission 17-06-2016, Peer Review 12-07-2016,

Acceptance 18-07-2016, Published 23-07-2016.

Corresponding Author:

Dr. Sanjay Gajanan Surase,

Assistant Professor,

Department of Pathology,

Grant Govt. Medical College,

J.J. Hospital, Byculla,

Mumbai-400008.

E-mail: sanajysurase@gmail.com

DOI: $10.14260 /$ jemds/2016/934
(15-49 age groups) HIV prevalence at national level $0.27 \%$ in 2011. The first AIDS case in India was detected in 1986 and since then HIV infection has been reported in all states and Union Territories.

Acquired Immunodeficiency Syndrome (AIDS) is known to be caused by a lymphotropic virus, which belongs to the Lentivirus genus of the Retroviridae family called as Human Immunodeficiency Virus (HIV), which was first described by French investigators and later by the investigators in United States. AIDS was first recognised in 1981.[5] The HIV virus can infect many tissues, but there are two major targets of the HIV infection, immune system and the central nervous system. The infection gets established in the lymphoid tissues followed by active viral replication leading to more infection of cells and progression to AIDS.

HIV infection is often associated with a number of opportunistic infections and malignancies, presenting with lymphadenopathy which is one of the earliest manifestations of HIV infection.[6] Now-a-days, there have been so many great advances made in the treatment of patients with HIV infections, so early diagnosis of the opportunistic infection is of the critical value in providing each patient with the best opportunity to live a long and healthy life despite the presence of HIV infection. ${ }^{[7]}$ 
In a developing country like India, which has a huge population and socioeconomic constraints, there is a great need of a simple investigation technique for early diagnosis of HIV lymphadenopathy patients.

Fine Needle Aspiration Cytology (FNAC) has a wellestablished role in the diagnosis of lymphoid lesions. Acquired Immunodeficiency Syndrome (AIDS) related lymphadenopathy has definite patterns like florid reactive hyperplasia, folliculosis, explosive follicular hyperplasia, advanced lymphocytic depletion with or without abnormal regressively transformed germinal centres and vascular transformation. Though FNAC cannot clearly demarcate all these lesions, it has definite identifiable reactive patterns described and is useful in detecting specific infective aetiologies. FNAC definitely carries lesser risk to the performer than the open biopsies. Burton $\mathrm{F}$ et al[8] did a retrospective study, where he had indicated that open biopsy is not indicated in the HIV or AIDS patients, especially with the non-tender or non-enlarging nodes, though it was the method of choice for diagnosing HIV infection before serological testing was freely available. The literature available is mostly of the western world. ${ }^{[9,10]}$ In Indian setting there is a different clinical presentation, clinical progress of the disease and the nature of the opportunistic infections in HIV positive and AIDS patients.

\section{AIMS AND OBJECTIVES}

The aim of the study was to evaluate the diagnostic utility of Fine Needle Aspiration Cytology (FNAC) for HIV positive lymphadenopathy patients and to analyse the different cytological diagnostic patterns of lymph node lesions in HIV/AIDS patients.

\section{MATERIALS AND METHODS}

This study was carried out in the Department of Pathology (Cytology section) of tertiary care teaching hospital for a period of two years from July 2013 to June 2015. In this hospital based prospective study, all the known cases of HIV with peripheral lymphadenopathy attending to cytology Outpatient Department (OPD) of hospital were enrolled. A total of 70 cases were studied, detailed clinical notes were taken, patient was examined and the findings were recorded. Fine needle aspiration was done and both alcohol fixed and air dried smears were prepared. Lymph node aspirates were stained routinely with Haematoxylin and Eosin (H\&E), Papanicolaou's stain (PAP), Giemsa and Ziehl and Neelsen (ZN) stain. All these stains were done in all the cases irrespective of the cytological findings. All superficial lymph node swellings of the body were included, while all nonlymphoid swelling aspirates were excluded from the study. Fine Needle Aspiration Cytology (FNAC) was done if the minimum size of the swelling measured about $1 \mathrm{~cm}$ and palpable if swelling was single. In case of multiple lymph node swellings, the smallest swelling measured up to $0.5 \mathrm{~cm}$ accepted considering at least any one swelling measured 1 $\mathrm{cm}$ or more in size. FNAC was done on the largest swelling. Sometimes aspiration was done from more than one node considering the size of the different nodes and nature and quantity of the material aspirated, especially if the sample was insufficient. The area was cleaned. A $10 \mathrm{~mL}$ syringe and 23-22 gauge needles were used for aspiration by using multiple passes. The microscopic glass slides used were cleaned, grease free and kept dry before making the smears. A total of 5-6 slides were prepared in each case. The smears were fixed immediately for Papanicolaou's and Haematoxylin and Eosin (H\&E) staining. The fixative consists of ether, alcohol mixture in proportion of 5:1. A commercial spray fixative (Carnoy's fixative) was also used as an alternative fixative at time. Air dried smears were stained with Giemsa stain. Heat fixed smears were stained with ZN stain. Occasionally, some aspirates consist of fluid which were collected separately in clean EDTA vacutainers and processed in the department. The nature of the aspirate varied from necrotic (Caseous), purulent, particulate to haemorrhagic fluid. Patient's consent was taken in all the cases before the procedure.

\section{OBSERVATION AND RESULTS}

\begin{tabular}{|c|c|c|c|c|}
\hline $\begin{array}{c}\text { Age Group } \\
\text { (In Years) }\end{array}$ & Male & Female & Total & Percentage \\
\hline $0-10$ & 0 & 0 & 0 & $0 \%$ \\
\hline $11-20$ & 2 & 1 & 03 & $4.29 \%$ \\
\hline $21-30$ & 5 & 5 & 10 & $14.29 \%$ \\
\hline $31-40$ & 18 & 16 & 34 & $48.57 \%$ \\
\hline $41-50$ & 13 & 06 & 19 & $27.14 \%$ \\
\hline $51-60$ & 02 & 02 & 04 & $5.71 \%$ \\
\hline Total & $\mathbf{4 0}$ & $\mathbf{3 0}$ & $\mathbf{7 0}$ & $\mathbf{1 0 0 \%}$ \\
\hline Table 1: Age and Gender Wise Distribution of \\
Lymphadenopathy in HIV Positive Patient \\
\hline \multicolumn{6}{|c}{} \\
\hline
\end{tabular}

Out of 70 HIV positive patients were included in this study, 40 (57.14\%) were male and 30 (42.86\%) were female. This shows male preponderance of cases. Male-to-female ratio was 1.3:1. Majority of both male and female patients were seen in the age group of 31-40 years. Numbers of cases at the extreme age groups are very less $(0 \%$ cases in $0-10$ and 51-60 years of age group).

\begin{tabular}{|c|c|c|}
\hline Site Involved & No. of Cases & Percentage \\
\hline Cervical & 47 & $67.14 \%$ \\
\hline Axillary & 08 & $11.44 \%$ \\
\hline Inguinal & 04 & $5.71 \%$ \\
\hline Submandibular & 04 & $5.71 \%$ \\
\hline Supraclavicular & 04 & $5.71 \%$ \\
\hline Pre-auricular & 02 & $2.86 \%$ \\
\hline Post-auricular & 01 & $1.43 \%$ \\
\hline Total & 70 & $100 \%$ \\
\hline \multicolumn{3}{|c|}{$\begin{array}{c}\text { Table 2: Site Wise Distribution of } \\
\text { Lymphadenopathy in HIV Positive Patient }\end{array}$} \\
\hline
\end{tabular}

From Table 2, it is evident that most common site of HIV lymphadenopathy is the cervical lymph nodes $47(67.14 \%)$, followed by axillary 08 (11.44\%), inguinal, submandibular and supraclavicular 04 (5.71\%) cases each.

\begin{tabular}{|c|c|c|}
\hline Site Involved & $\begin{array}{c}\text { No. of } \\
\text { Cases }\end{array}$ & Percentage \\
\hline Tuberculous Lymphadenitis & 42 & $60.00 \%$ \\
\hline Reactive Lymphadenitis & 12 & $17.14 \%$ \\
\hline Suppurative Lymphadenitis & 06 & $8.57 \%$ \\
\hline $\begin{array}{c}\text { Nonspecific Chronic } \\
\text { Granulomatous Lymphadenitis }\end{array}$ & 05 & $7.14 \%$ \\
\hline Non-Hodgkin's Lymphoma & 02 & $2.86 \%$ \\
\hline
\end{tabular}




\begin{tabular}{|c|c|c|}
\hline Metastasis of SCC & 02 & $2.86 \%$ \\
\hline $\begin{array}{c}\text { Metastasis of Germ Cell } \\
\text { Neoplasm }\end{array}$ & 01 & $1.43 \%$ \\
\hline Total & $\mathbf{7 0}$ & $\mathbf{1 0 0 \%}$ \\
\hline $\begin{array}{c}\text { Table 3: Distribution of Cases According } \\
\text { to Cytological Diagnosis }\end{array}$ \\
\hline
\end{tabular}

\begin{tabular}{|c|c|c|}
\hline Site Involved & $\begin{array}{l}\text { No. of } \\
\text { Cases }\end{array}$ & Percentage \\
\hline $\begin{array}{c}\text { Smears showing only Caseous } \\
\text { Necrosis }\end{array}$ & 02 & $4.09 \%$ \\
\hline $\begin{array}{l}\text { Smears showing Caseous } \\
\text { Necrosis with Epithelioid } \\
\text { Cells }\end{array}$ & 42 & $85.71 \%$ \\
\hline $\begin{array}{l}\text { Smears showing only } \\
\text { Epithelioid Cells }\end{array}$ & 05 & $10.20 \%$ \\
\hline Total & 49 & $100 \%$ \\
\hline \multicolumn{3}{|c|}{$\begin{array}{c}\text { Table 4: Cytological Pattern of Granulomatous } \\
\text { Lymphadenitis (Including Tuberculous } \\
\text { Lymphadenitis) in HIV Patients }\end{array}$} \\
\hline
\end{tabular}

In this study tuberculous infection was the most common opportunistic infection, which was grouped into caseous necrosis with epithelioid cell granulomas in Table 4. Interestingly, two cases of tuberculosis were diagnosed in which there were only caseous necrosis in the FNA smears and the same was confirmed by presence of acid fast bacilli in ZN stain.

\begin{tabular}{|c|c|c|}
\hline Site Involved & No. of Cases & Percentage \\
\hline$<2 \times 2 \mathrm{~cm}$ & 55 & $78.57 \%$ \\
\hline$>2 \times 2 \mathrm{~cm}$ & 15 & $21.43 \%$ \\
\hline Total & $\mathbf{7 0}$ & $\mathbf{1 0 0 \%}$ \\
\hline \multicolumn{2}{|r|}{ Table 5: Size Wise Distribution of } \\
Lymphadenopathy in HIV Patients \\
\hline
\end{tabular}

In most of the cases (78.57\%), the size was less than $2 \times 2$ $\mathrm{cm}$. In our study, the largest size of swelling was $10 \times 8 \mathrm{cms}$ in one case. In two cases, it measured up to $5 \mathrm{~cm}$, while in 7 cases it was $3 \mathrm{cms}$. In rest of the cases it was less than $3 \mathrm{~cm}$. The smallest size of the swelling in this study was $0.5 \times 0.5 \mathrm{~cm}$ (46 words).

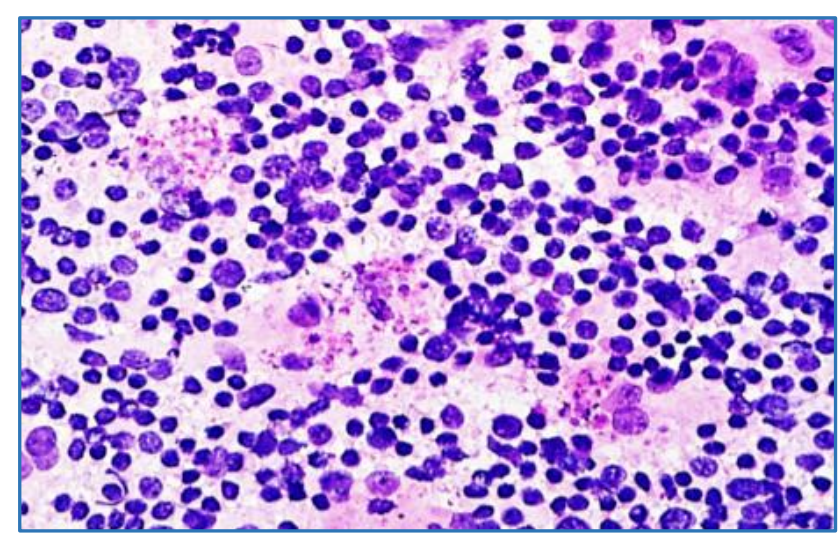

Fig. 1: Aspirates from Reactive Hyperplasia of Lymph Node with Lymphocytes in Various Stages of Maturation and Transformation (H\&E 40x)

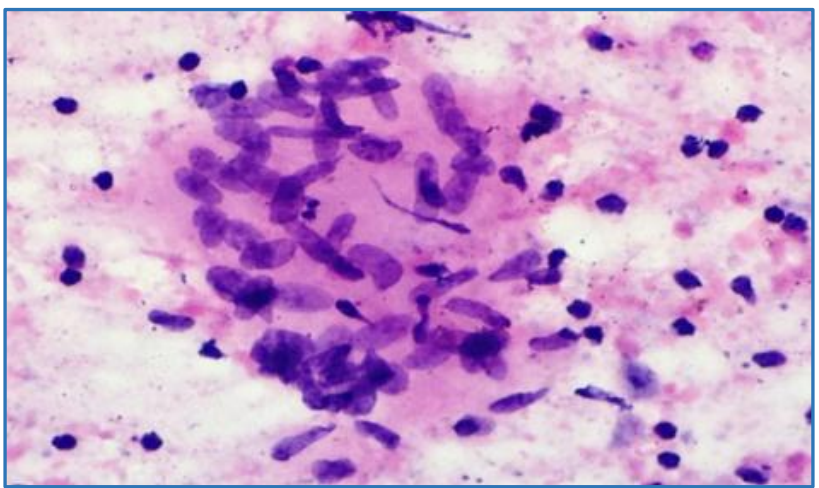

Fig. 2: Aspirates from Tuberculous Lymph Node with an Epithelioid Cell Granuloma (H\&E 40x)

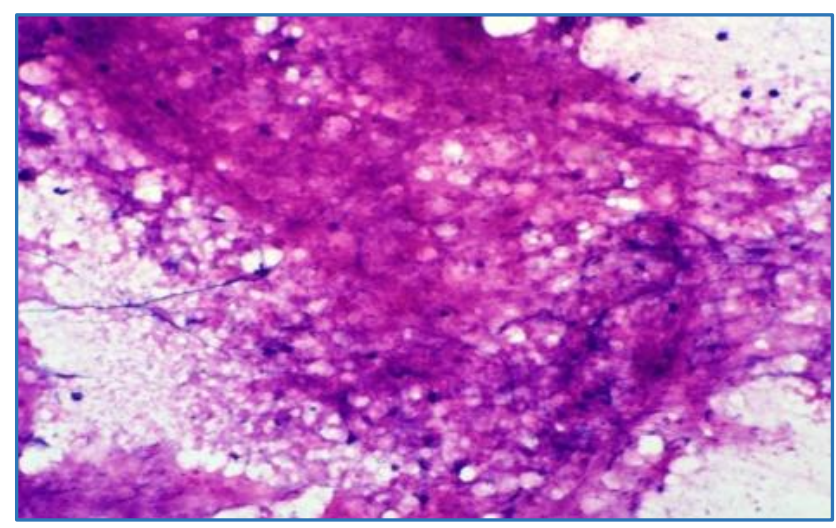

Fig. 3: Caseous Necrosis in Aspirates from Tuberculous Lymph Node (H\&E 40x)

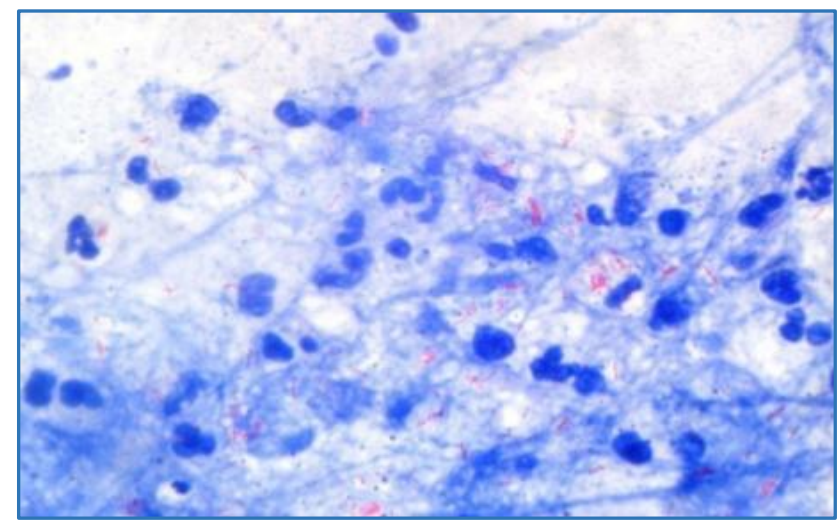

Fig. 4: Acid Fast Bacilli in Aspirates from Tuberculous Lymph Node (ZN 100x)

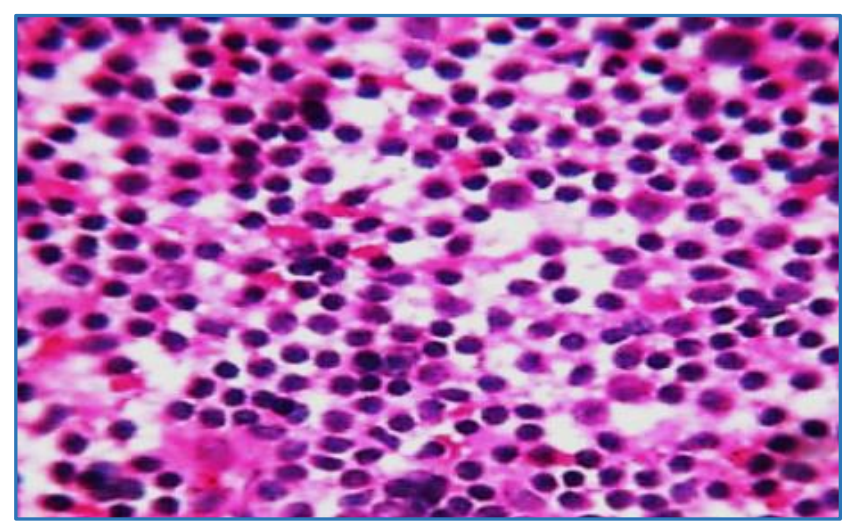

Fig. 5: Aspirates from Non-Hodgkin's Lymphoma (Centroblastic Variant) (H\&E 40X) 


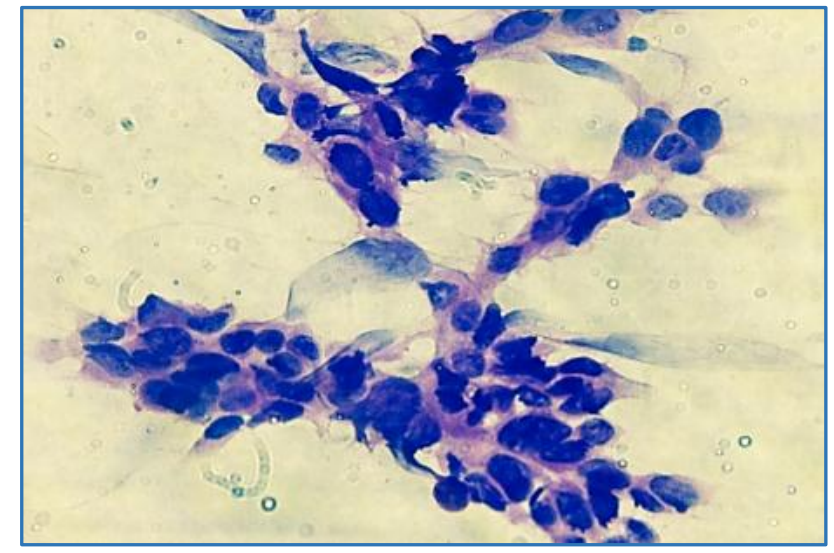

Fig. 6: Aspirates from Metastatic Squamous Cell Carcinoma with Malignant Squamous Cells arranged in Sheets (H\&E 40x)

\section{DISCUSSION}

In the present study, FNAC was carried on in $70 \mathrm{HIV}$ positive patients. Out of them, $40(57.14 \%)$ were males and 30 $(42.86 \%)$ were females with a male-to-female ratio of 1.3:1. Parikh U.R. et al[11], Bates E.M. et al[12] and Saikia U.N. et al[3] reported much higher male predominance in their studies. While other studies like Deshmukh A.T. et al[13] mentioned the ratio to be 1.7:1, Laishram R.S. (1:0.35).[14], Ratan K. et al (1.2:1).[15] similar to this study. Out of 70 patients $3(4.29 \%)$ patients were between 11-20 years of age, 10 (14.29\%) were between 21-30 years, 34 (48.57\%) were between 31-40 years, 19 (27.14\%) were between 41-50 years and 4 (5.71\%) patients were between 51-60 years of age. So maximum of the affected patients were seen in the age group of 31-40 years. Desmukh A.T. et al[13] in their study also mentioned that the same age group affected in males, but for females it was between 21-30 years. These differences in age and sex distributions may be due to differences in the incidence, prevalence and mode of transmission in different geographic locations. Cervical group of lymph nodes were the most common site of involvement. This study is comparable with studies of Parikh U.R. et al[11] and Bates E.M. et al.[12]

In India the most common opportunistic infection in AIDS patients is tuberculosis.[16] In our study, tuberculous lymphadenitis constituted about 42 (60\%) cases. Similar findings were also observed in various studies conducted by Shenoy et al[17] with $50 \%$ in Mangalore, Vanisri et al[5] with $58.3 \%$, Laishram R.S. ${ }^{114]}$ with $42.19 \%$ in Imphal. Kumar N. et al[18] reported $74 \%$ cases of tuberculous lymphadenitis. Llatjos et al[19] observed and described three cytological patterns in AIDS patients diagnosed as having tuberculous lymphadenitis are granulomatous lymphadenitis, necrotising granulomatous lymphadenitis and necrotising lymphadenitis. However, a definite cytologic diagnosis of tuberculous lymphadenitis can be offered in smears with caseating granulomas with or without giant cells. ZN staining should be performed on all aspirates from cases of suspected tuberculosis. In present study, granuloma without caseous necrosis was observed in $5(10.20 \%)$ cases. Only caseous necrosis was observed in $2(4.09 \%)$ cases and both were AFB positive. Caseous necrosis along with epithelioid cell granuloma was observed in $42(85.71 \%)$ cases. In the study conducted by Shenoy et al[17], granulomas without caseous necrosis was observed in $43 \%$ of cases and only caseous necrosis was observed in $8.7 \%$ cases. Caseous necrosis with epithelioid cell granuloma was observed in $74 \%$ cases.

Out of the 70 cases, 29 cases presented with past history or contact with tuberculosis. Out of 42 cases of tuberculosis, AFB positivity was seen in 4 cases $(9.52 \%)$. It can be due to treatment status of the patients at the time of FNAC. Considering the increased prevalence of the disease in this locality, anti-tubercular treatment is started in most cases with clinical suspicion by the clinicians. Vanisri et al[5] mentioned AFB positivity of 7 cases out of 21 diagnosed cases (33.33\%) of mycobacterial infection.

Reactive lymphadenitis was the second most common lesion diagnosed in this study (17.14\%). Similar observations were also contributed by Saikia et al[3], Vanisri et al.[5] Another study done by Ratan K. et al[15] in Imphal mentioned the most common lesion to be non-specific reactive lymphadenitis constituted about $42.1 \%$ followed by tuberculous lymphadenitis (38.84\%). All the cases of reactive lymphadenitis were negative for AFB. Satyanarayana et al[20] in their study reported a reactive cytomorphological pattern in $16.4 \%$ of their cases of tuberculosis. Bottles et al[21] in their study on HIV lymphadenopathy mentioned that $50 \%$ aspirate showed reactive lymphoid hyperplasia, Picerno I et al[22] and Reid et al[10] found reactive hyperplasia in $41 \%$ and $51 \%$ aspirates respectively.

We reported $6(8.57 \%)$ cases of suppurative lymphadenitis. ZN stain was negative and the smears showed mostly neutrophils with scant lymphocytes in a necrotic background. The aspirates were purulent. Laishram SR et $\mathrm{al}^{[14]}$ in their studies reported $10.94 \%$ cases of suppurative lymphadenitis. Vanisri et al[5] reported $2.7 \%$ cases, which was also ZN negative. Shenoy et al[17] reported 3 (13\%) patients with acute suppurative lymphadenitis with AFB positivity.

In this study, we reported $5(7.14 \%)$ malignant cases. Laishram RS et al[14] reported $4.69 \%$, while Shenoy et al[17] reported $12.5 \%$ malignant cases in their studies. Deshmukh et al[13] in Amravati did not report any malignant case in their study on 44 HIV positive patients.

Non-Hodgkin's lymphoma (NHL) is the most common malignancy to occur in HIV positive patients. In the present study, we reported $2(2.86 \%)$ cases of NHL further typing of which was not possible. Vanisri et al[5] and Saikia et al[3] reported 1 case of NHL each.

Kaposi's sarcoma is the other malignancy commonly occurring in HIV positive patients. We did not find any case of Kaposi's sarcoma. Muyanja et al[23] in Uganda, reported 10.2\% cases of Kaposi's sarcoma. It is most probably due to the geographical variation of the disease, which is more common in Western and African countries than India.

Other than lymphoma, we diagnosed $2(2.86 \%)$ cases of metastasis of squamous cell carcinoma and $1(1.43 \%)$ case of metastasis of germ cell neoplasm. Saikia et al[3] reported 1 case of metastatic squamous cell carcinoma. Some evidence has shown that men infected with the Human Immunodeficiency Virus (HIV), particularly those with AIDS are at increased risk for germ cell neoplasm. No other infections have been shown to increase testicular cancer risk.[24]

On following up the case, biopsy was known to be done in our institute. Diagnosis was given as metastasis of germ cell neoplasm-seminoma. 
In the present study other than mycobacterium tuberculosis, we did not identify any other opportunistic infection in any of the lymph node swelling cases. Shenoy et al[17], Vanisri et al[5] and Deshmukh et al[13] also did not find any other opportunistic infection in their studies. Though, Satyanarayana et al[20] reported one case of Cryptococcus and one case of Rhodotorula in their studies.

\section{CONCLUSION}

Based on this study FNAC is found to be comparatively reliable, cost effective, inexpensive and useful technique with less risk to the exposure for evaluation and identification of opportunistic infections, neoplastic lesions and nonneoplastic lesions because of its lack of complications and excellent results. FNAC is a quick and repeatable procedure. It may spare patient's lymph node excision and enable immediate treatment of specific infection. Tuberculous lymphadenitis was the commonest lesion diagnosed. It could be diagnosed both in symptomatic and asymptomatic patients even in a lymph node of very small size. ZN stain should be done in all the cases and AFB should be looked for even if the cytological picture does not suggest tuberculosis. FNAC in HIV patients help in segregating cases, which requires further evaluation. The neoplastic lesions if diagnosed need biopsy/immunohistochemistry for typing, specially in non-Hodgkin's lymphoma. Non-neoplastic conditions like chronic granulomatous lymphadenitis need the help of biopsy for aetiological workup.

\section{REFERENCES}

1. Global report: UNAIDS report on the global AIDS epidemic 2012, available from http://www.unaids.org/en/media/unaids/contentasset s/documents/epidemiology/2012/gr2012/20121120 unaids global report 2012 with annexes en, on 10 July 2012.

2. NACO Annual Report 2012-13, available from http://www.naco.gov.in/upload/Publication/AnnualRep ort2012-13, on 10 July 2012.

3. Saikia UN, Dev P, Jindal B, et al. Fine needle aspiration cytology in lymphadenopathy of HIV positive cases. Acta Cytol 2001;45(4):589-92.

4. Beck JM, Rosen MJ, Peavy HH, et al. Pulmonary complication of HIV. AM J Resp Critical Care Medicine 2001;164(11):2126-9.

5. Vanisri HR, Nandini NM, Sunita R. Fine- needle aspiration cytology findings in human immunodeficiency virus lymphadenopathy. IJPM 2008;51(4):481-4.

6. Jayaram G, Chew MT. Fine needle aspiration cytology of lymph nodes in HIV-infected. Acta Cytol 2000;44(6): 960-6.

7. Baghel PS, Gupta A, Singh KR, et al. A study on use of FNAC for the diagnosis of lymphadenopathy in HIV positive patients compared to conventional biopsy and correlation of findings with CD4 count. J of Evol of Med and Dental Sci 2013;48(2):9261-8.

8. Burton F, Patete ML, Goodwin WJ. Indications for open cervical node biopsy in HIV positive patients. Otolaryngol Head Neck Surg 1992;107(3):367-9.
9. Houn HY, Pappas AA, Walker EM. Lymph node pathology of acquired immunodeficiency syndrome (AIDS). Ann Clin Lab Sci 1990;20(5):337-42.

10. Reid AJ, Miller RF, Kocjan GI. Diagnostic utility of fine needle aspiration cytology in HIV- infected patients with lymphadenopathy. Cytopathology 1988;9(4):230-9.

11. Parikh UR, Goswami HM, Bisen VV, et al. Diagnostic utility of FNAC in HIV positive lymphadenopathy. J of Clin Res Letters 2012;3(2):37-40.

12. Bates EM, Tanner A, Suvarna SK, et al. Use of fine needle aspiration cytology for investigating lymphadenopathy in HIV positive patients. J Clin Pathol 1993;46(6):564-6.

13. Desmukh AT, Jagtap MW, Nafees N. Cytological evaluation of lymphadenopathy in HIV patients. Int J of Recent Trends in Sci and Tech 2013;3(6):125-9.

14. Laishram RS, Devi RKT, Khuraijam S, et al. Fine needle aspiration cytology of HIV-related lymphadenopathy in Manipur. JIACM 2014;15(2):111-5.

15. Ratan K, Singh BN, Kumar AK, et al. Cytomorphological diagnosis of lymphadenopathy by fine needle aspiration cytology in HIV positive patients and its correlation with CD4 count-a hospital based 2 years cross sectional study. IOSR Journal of Dental and Medical Sciences (IOSRJDMS) 2014;13(7):49-54.

16. Kumarasamy N, Solomon S, Paul JSA, et al. Spectrum of opportunistic infections among AIDS patients in Tamil Nadu, India. Int J STD AIDS 1995;6(6):447-9.

17. Shenoy R, Kapadi SN, Pai KP, et al. Fine needle aspiration diagnosis in HIV- related lymphadenopathy in Mangalore, India. Acta Cytol 2002;46(1):35-9.

18. Kumar N, Gupta BB, Sharma B, et al. Role of fine needle aspiration cytology in human immunodeficiency virusassociated lymphadenopathy: a cross-sectional study from northern India. Hong Kong Med J 2015;21(1):3844.

19. Llatjos M, Romeu J, Clotet B, et al. A distinctive cytologic pattern for diagnosing tuberculous lymphadenitis in AIDS. J Acquir immune Defic Synd 1993;6(12):1335-8.

20. Satyanarayana S, Kalghatgi AT, Muralidhar A, et al. Fine needle aspiration cytology of lymph nodes in HIV infected patients. Med J Armed Forces India 2002;58(1):33-7.

21. Bottles K, McPhaul LW, Volberding P. Fine needle aspiration biopsy of patients with acquired immunodeficiency syndrome (AIDS): experience in an outpatient clinic. Ann Intern Med 1988;108(1):42-5.

22. Picerno I, Visalli $G$, Lentile $R$, et al. Lymph node involution, T-cell adaptation and T-cell death in HIV infection. HIV Therapy 2010;4(6):629-37.

23. Muyanja D, Kalyesubula R, Namukwaya E, et al. Diagnostic accuracy of fine needle aspiration cytology in providing a diagnosis of cervical lymphadenopathy among HIV-infected patients. Afr Health Sci 2015;15(1): 107-16.

24. http://www.cancer.org/acs/groups/cid/documents/we bcontent/003142-pdf.pdf. 